$1-1-2002$

\title{
Stable Isotopes of Carbon as an Invaluable Stratigraphic Tool: An Example from the Cambrian of the Northern Appalachians, USA
}

\author{
Bosiljka Glumac \\ Smith College, bglumac@smith.edu \\ Malkah L. Spivak-Birndorf \\ Smith College
}

Follow this and additional works at: https://scholarworks.smith.edu/geo_facpubs

Part of the Geology Commons

\section{Recommended Citation}

Glumac, Bosiljka and Spivak-Birndorf, Malkah L., "Stable Isotopes of Carbon as an Invaluable Stratigraphic Tool: An Example from the Cambrian of the Northern Appalachians, USA" (2002). Geosciences: Faculty Publications, Smith College, Northampton, MA.

https://scholarworks.smith.edu/geo_facpubs/160 


\title{
Stable isotopic $\left(\delta^{13} \mathrm{C}\right.$ and $\left.\delta^{18} \mathrm{O}\right)$ signatures of biogenic calcretes marking discontinuity surfaces: a case study from Upper Cretaceous carbonates of central Dalmatia and eastern Istria, Croatia
}

\author{
Mihovil Brlek • Bosiljka Glumac
}

Received: 10 February 2014/ Accepted: 28 April 2014/Published online: 14 May 2014

(C) Springer-Verlag Berlin Heidelberg 2014

\begin{abstract}
Biogenic calcretes associated with a regional Cretaceous to Paleogene subaerial unconformity and an intraformational composite (polygenic) surface in Upper Cretaceous intra-platform peritidal successions in central Dalmatia and eastern Istria, Croatia (Adriatic-Dinaridic Carbonate Platform), were analyzed for their $\delta^{13} \mathrm{C}$ and $\delta^{18} \mathrm{O}$ signatures in order to provide insight into the conditions of subaerial exposure and calcrete development. The distinctly negative $\delta^{13} \mathrm{C}$ signatures of biogenic calcretes marking the regional subaerial unconformity differ considerably from the $\delta^{13} \mathrm{C}$ values of the host marine limestones. This indicates carbon isotope exchange of primary marine $\mathrm{CaCO}_{3}$ with $\mathrm{CO}_{2}$ released by root and rhizomicrobial respiration and subsequent precipitation of pedogenic calcrete. The range of $\delta^{13} \mathrm{C}$ (from -13.1 to $-8.2 \%$ Vienna PeeDee Belemnite standard, VPDB) and $\delta^{18} \mathrm{O}$ (from -10.1 to $-6.1 \%$ VPDB) values of calcretes are similar to those reported from calcretes elsewhere, and the $\delta^{13} \mathrm{C}$ values of biogenic calcretes with typical Microcodium aggregates ( -13.1 to $-12.3 \%$ VPDB) at the Šibenik locality are very close to, or at the lower limit of, values for soil carbonates formed in isotopic equilibrium with soil $\mathrm{CO}_{2}$. These values are expected for authigenic pedogenic carbonates formed under the influence of $\mathrm{C}_{3}$ plant communities, without influence from heavier carbon from preexisting carbonate and lack of input of atmospheric $\mathrm{CO}_{2}$. Such low $\delta^{13} \mathrm{C}$ values support the interpretation of
\end{abstract}

\footnotetext{
M. Brlek ( $\square)$

Department of Geology, Croatian Geological Survey,

Sachsova 2, 10000 Zagreb, Croatia

e-mail: mihovil.brlek@hgi-cgs.hr

B. Glumac

Department of Geosciences, Smith College,

Northampton, MA 01063, USA
}

Microcodium aggregates as being precipitated under a direct biological control within the soil, although the relationship between formation mechanisms and stable isotope signatures of Microcodium needs further investigation. The $\delta^{13} \mathrm{C}$ values (-4.4 to $-3.6 \%$ VPDB) of rhizogenic calcretes formed inside firmground Thalassinoides burrows of the composite surface at the Šibenik locality are more negative than the $\delta^{13} \mathrm{C}$ values of the host marine limestones, which confirms that the composite surface went through a phase of meteoric pedo(dia)genesis. However, the overall $\delta^{13} \mathrm{C}$ values of calcretes are less negative than expected, which might reflect contamination from associated primary marine carbonate. This study represents the first detailed stable isotope investigation of calcretes from carbonate successions of the External Dinarides, and the results may be applied to discontinuities present in other shallow-water carbonate rock successions.

Keywords Biogenic calcretes $\cdot \delta^{13} \mathrm{C} \cdot \mathrm{Pedo}(\mathrm{dia})$ genesis . Discontinuity surfaces - Upper Cretaceous · Croatia

\section{Introduction}

Biogenic (or beta microfabric) calcretes with rhizoliths represent profound indicators of subaerial exposure of carbonate successions (e.g., Wright 1994; Immenhauser et al. 2000; Alonso-Zarza and Jones 2007; Brlek et al. 2014), and are also common in paleokarstic horizons and palustrine deposits (Freytet and Plaziat 1982; Košir 2004). Remains of calcified roots are also a typical feature of loess-paleosoil successions (e.g., Becze-Deák et al. 1997; Barta 2011; Gocke et al. 2011a, 2014). Distinct stable isotope signatures of calcretes and altered marine limestones have often been used for recognition of meteoric 
diagenesis of carbonate successions (e.g., Allan and Matthews 1982; James and Choquette 1990; Deák et al. 2002; $\mathrm{Li}$ and Jones 2014) due to carbon isotope exchange of primary marine $\mathrm{CaCO}_{3}$ with $\mathrm{CO}_{2}$ released by root and rhizomicrobial respiration and subsequent precipitation of pedogenic calcrete (Cerling 1984; Gocke 2010). Secondary carbonates in soils and paleosoils may form in isotopic equilibrium with soil $\mathrm{CO}_{2}$ (Cerling 1984, 1999), which derives mainly from root respiration and microbial decomposition of soil organic matter (Amundson et al. 1998). Such carbonates are therefore used as an important tool for the reconstruction of paleoenvironmental conditions, by means of stable isotope $\left(\delta^{13} \mathrm{C}\right.$ and $\left.\delta^{18} \mathrm{O}\right)$ analysis, as well as for radiocarbon dating $\left({ }^{14} \mathrm{C}\right)$ of Quaternary soils and paleosoils (e.g., Pustovoytov and Terhorst 2004; Pustovoytov et al. 2007; Wang and Greenberg 2007; Monger et al. 2009; Zhou and Chafetz 2009a, 2010; Gocke 2010; Gocke et al. 2011a; Koeniger et al. 2014). In addition, information derived from the studies of pedogenic carbonate formation and post-segregational alteration processes, also proved to be of relevance for paleoenvironmental studies of Quaternary terrestrial sedimentary sequences (e.g., Gocke et al. 2010, 2011b, 2012; Gocke and Kuzyakov 2011). Under equilibrium conditions, the metabolic pathway of vegetation (e.g., $\mathrm{C}_{3}$ and $\mathrm{C}_{4}$ plants) has an influence on carbon isotopic composition of soil $\mathrm{CO}_{2}$, which affects $\delta^{13} \mathrm{C}$ values of secondary carbonates (Cerling 1984, 1999; Gocke et al. 2011a; Koeniger et al. 2014). However, other formation mechanisms, such as calcite precipitation directly within plant root cells from solutions containing organic compounds (Łącka et al. 2009; Koeniger et al. 2014), or metabolic activity of rhizosphere bacteria, microbes, and fungi (Kabanov et al. 2008; Koeniger et al. 2014), may influence $\delta^{13} \mathrm{C}$ values of precipitated products. In such cases, the $\delta^{13} \mathrm{C}$ values of calcified root cells and Microcodium aggregates, whose formation is most commonly interpreted as biologically controlled precipitation of calcium carbonate in cortical plant root cells and its subsequent morphological transformation (see Košir 2004 and references therein; or alternatively as calcification product of rhizosphere bacteria and fungi; Kabanov et al. 2008), may be lowered below the lower limit values for equilibrium pedogenic carbonates ( -12 to $-13 \%$ PDB; Cerling 1984; Burns and Rossinsky 1989; Kabanov et al. 2008; Koeniger et al. 2014).

Biogenic calcretes with rhizoliths characterize the regional Cretaceous to Paleogene $(\mathrm{K}-\mathrm{Pg})$ subaerial unconformity recorded in Upper Cretaceous to Paleocene marine carbonate deposits in central Dalmatia (Island of Hvar and Šibenik locality; Brlek et al. 2014; Island of Čiovo; Brlek et al. 2013). This subaerial unconformity has also been recorded in other Upper Cretaceous deposits across the Adriatic-Dinaridic Carbonate Platform (ADCP sensu
Korbar 2009) domain (also named the Adriatic Carbonate Platform-AdCP sensu Vlahović et al. 2005), including eastern Istria (e.g., Koromačno locality; Otoničar 2007). In addition, a composite surface (polygenic surface formed during both submarine omission and subsequent subaerial exposure phase; see Immenhauser et al. 2000; Brlek et al. 2014) recorded within the Upper Cretaceous carbonate succession at Šibenik is also characterized by rhizogenic laminar calcretes that infilled Thalassinoides paradoxicus burrows of the Glossifungites ichnofacies, and diagenetically overprinted primary marine deposits (Brlek et al. 2014). The purpose of the present study is to obtain $\delta^{13} \mathrm{C}$ and $\delta^{18} \mathrm{O}$ values of biogenic calcretes and diagenetically altered marine limestones associated with these discontinuity surfaces in order to provide additional information on conditions of subaerial exposure and composite surface formation, whose detailed pedogenic, ichnological, and stratigraphic investigation has been provided by Brlek et al. (2013, 2014). Stable isotope signatures of the analyzed calcretes also provide insight into formation mechanisms and paleoenvironmental conditions of calcrete development, and add to the database of stable isotope values of soil carbonates in general. These results represent the first detailed stable isotope study of calcretes and meteoric diagenesis in Mesozoic to Cenozoic carbonate successions of the ADCP now exposed within the External Dinarides of Croatia, and are applicable to discontinuities present in shallow-water carbonate rock successions elsewhere.

\section{Geological setting}

The Upper Cretaceous carbonates of central Dalmatia (Šibenik locality and the Island of Čiovo, Croatia; Fig. 1ac) and eastern Istria (Labin-Koromačno area; Fig. 1a, b, d) were deposited in the southern and northern parts, respectively, of the long-lasting (Late Triassic to Paleogene) Adriatic-Dinaridic Carbonate Platform environment (ADCP) (sensu lato, cf. Pamić et al. 1998). This carbonate platform was a typical central Tethyan ("peri-Adriatic") or central-northern Mediterranean Mesozoic (sub)tropical archipelago, characterized by a thick succession of carbonate deposits and a complex large-scale facies architecture (Vlahović et al. 2005). The typical Upper Cretaceous stratigraphy of the south-central part of the Adriatic Carbonate Platform (ACP) (sensu stricto, cf. Jenkyns 1991; Korbar 2009) has been described in detail from the Island of Brač (Gušić and Jelaska 1990; Cvetko Tešović et al. 2001; Moro et al. 2002; Steuber et al. 2005), and is characterized by an over 1,500-m-thick peritidal succession punctuated by two drowning episodes.

The intra-platform peritidal Gornji Humac Formation extends regionally across the ADCP domain (Korbar 2009 

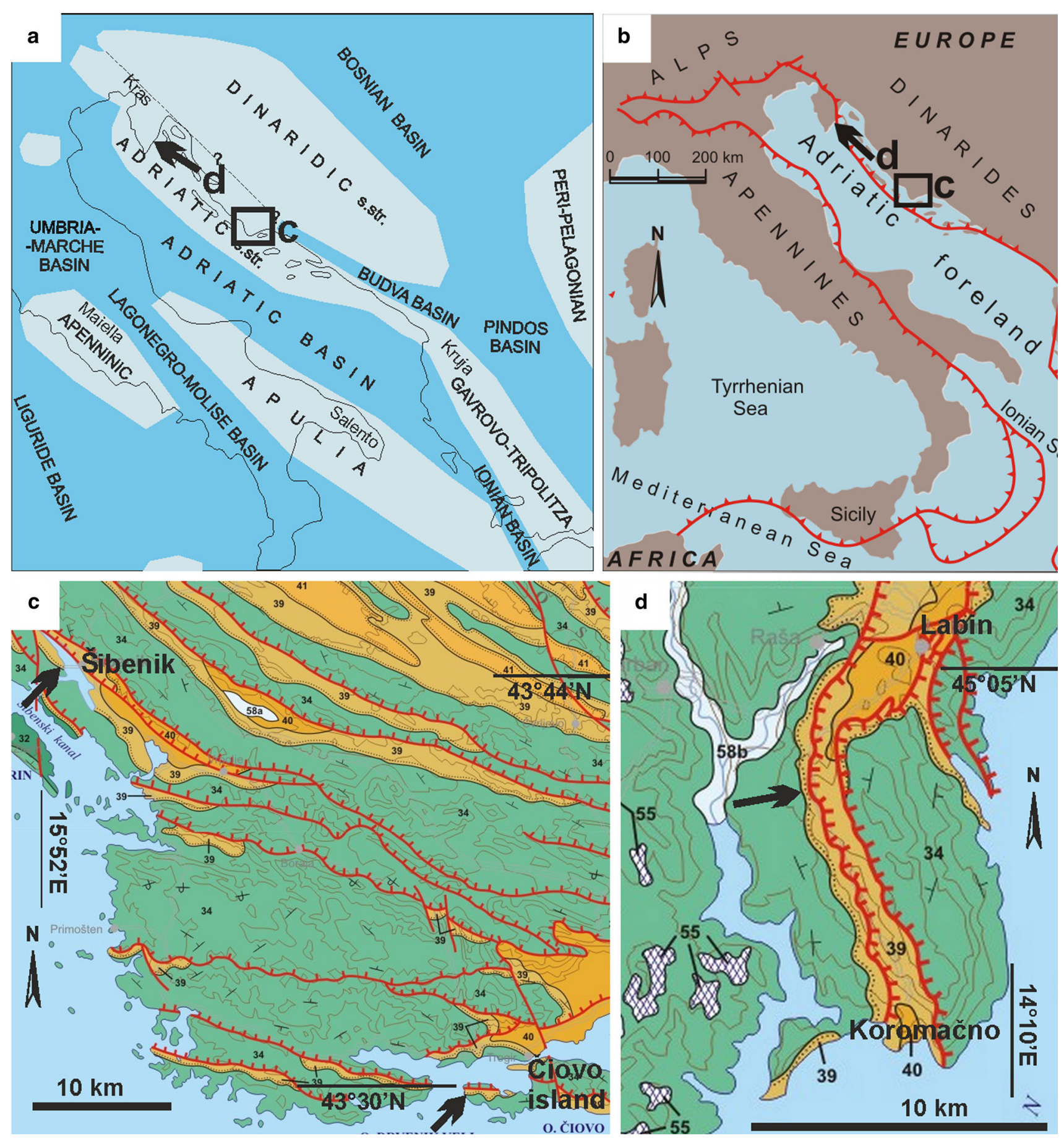

Fig. 1 Locality maps. a, b Position of the Šibenik, Čiovo (rectangle $c$ in $\mathbf{a}$ and $\mathbf{b}$ ) and Labin-Koromačno (black arrow $d$ in $\mathbf{a}$ and b) localities on the paleogeographic sketch-map (a) showing the periAdriatic carbonate platforms and shelves (white), and on the tectonic map (b) (modified from Korbar 2009). c, d Parts of the geological map of the Republic of Croatia 1:300,000 (GKRH 2009) (marked by rectangles and arrows in $\mathbf{a}$ and $\mathbf{b}$ ) showing the simplified geology of

and references therein). The age of the middle part of the succession is Coniacian to Santonian (recorded also at the Šibenik locality; Figs. 1c, 2), as shown mainly by the central Dalmatia (Croatia) with position of the Šibenik and Čiovo localities (c, black arrows), as well as of eastern Istria with position of the Labin-Koromačno locality (d, black arrow). Color codes: green Upper Cretaceous carbonates (34), orange Paleogene carbonates (39) and siliciclastics (40 and 41), white Quaternary deposits (55, 58a, and $b$ )

assemblages of larger benthic foraminifera (Gušić and Jelaska 1990; Velić 2007; Brlek et al. 2014) and by strontium isotope stratigraphy (Steuber et al. 2005). The 
Fig. 2 Stratigraphic column of the limestone succession of the Coniacian to Santonian Gornji Humac Formation from the Šibenik locality, with legend
Š I B E N I K

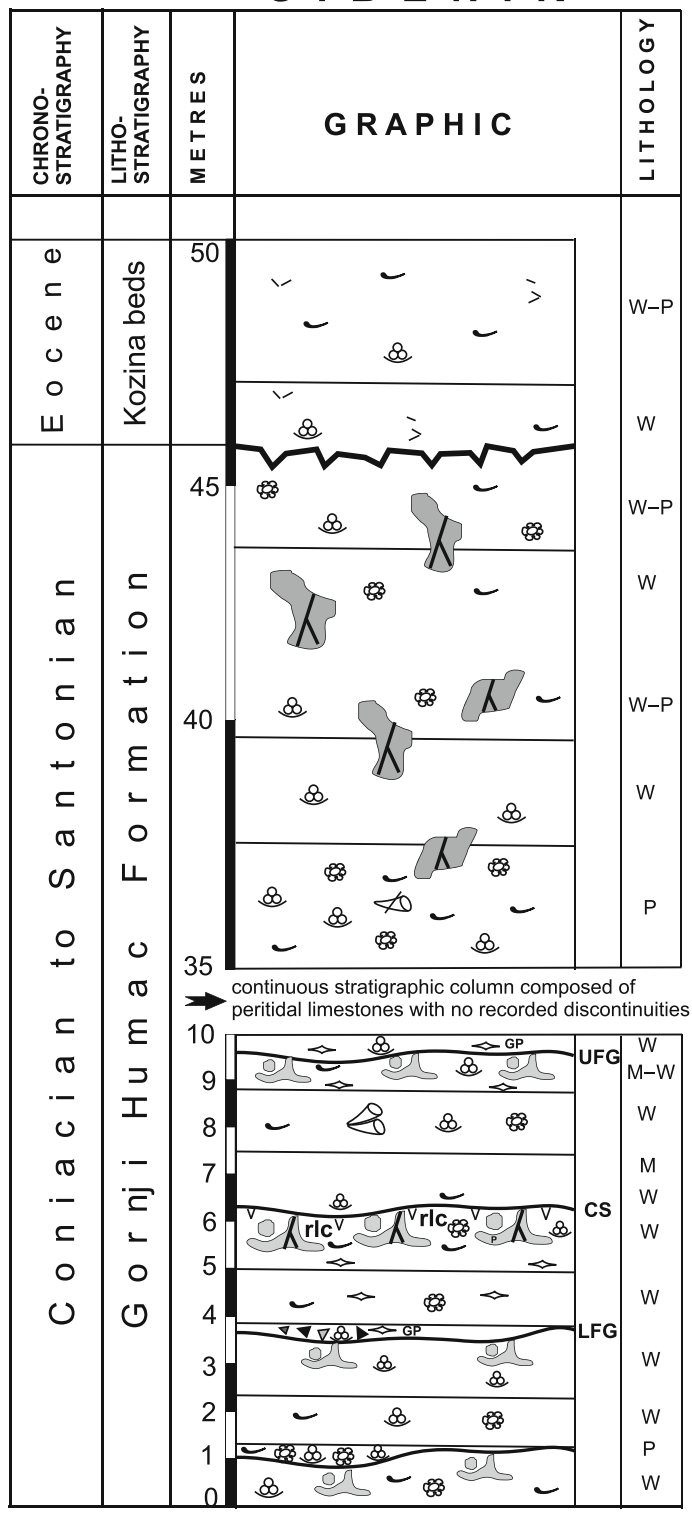

\section{LEGEND}

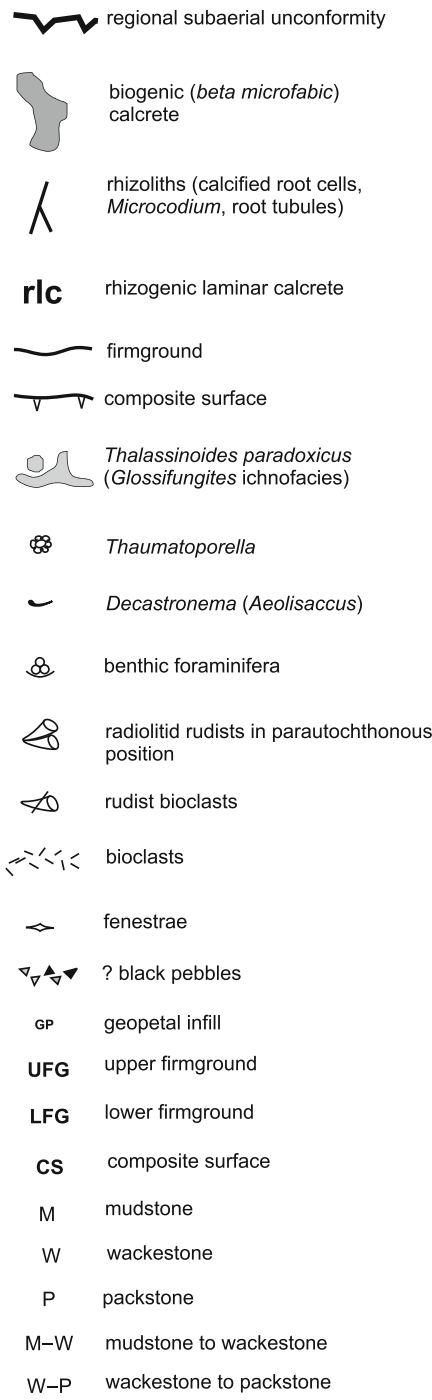

Gornji Humac Formation also represents an Upper Cretaceous intra-platform peritidal carbonate succession in the Labin-Koromačno area (Otoničar 2007; Korbar 2009).

The Upper Campanian Čiovo Formation of the Island of Čiovo is represented by outer ramp deposits (Brlek et al. 2013) that differ substantially from the penecontemporaneous typical inner-platform Adriatic-Dinaridic Carbonate Platform deposits common elsewhere in the central Dalmatian region (e.g., the Sumartin Formation on Brač Island; Gušić and Jelaska 1990). Upper Cretaceous to Paleogene deeper-water slope and ramp deposits recorded along the NE Adriatic coast of Croatia in central and southern Dalmatia (e.g., Vlahović et al. 2005; Ćosović et al. 2006; Korbar 2009; Brlek et al. 2013) indicate differentiation of the depositional environments within the
ADCP domain and a rather complex depositional, tectonostratigraphic, and paleogeographic setting of the region in Late Cretaceous to Paleogene times.

Transgressive Paleogene deposits, which unconformably overlie the Gornji Humac Formation at the Šibenik locality (Figs. 1c, 2) and in the Labin-Koromačno area (Fig. 1d), as well as the Čiovo Formation on the Island of Čiovo (Fig. 1c), are referred to as the Paleogene Kozina Beds (lowermost part of the Foraminiferal limestones exposed at the Šibenik locality and Labin-Koromačno area; Otoničar et al. 2003; Otoničar 2007; Brlek et al. 2014) and the Lower to Middle Eocene Foraminiferal limestones (on the Island of Čiovo; Brlek et al. 2013). Foraminiferal limestones are present regionally all across the ADCP (Gušić and Jelaska 1990; Schweitzer et al. 2007; Ćosović 

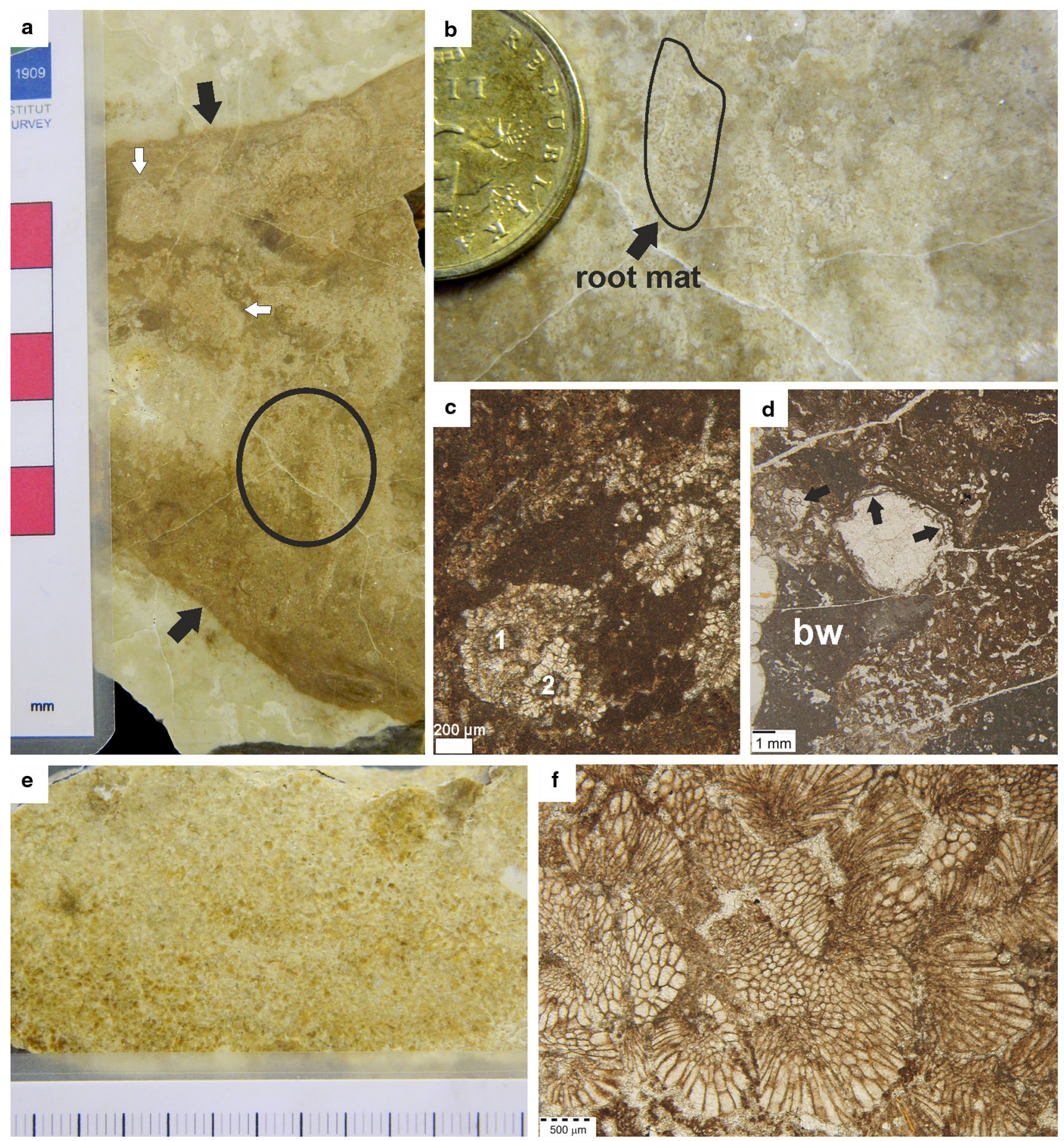

Fig. 3 Characteristics of the first $(\mathbf{a}-\mathbf{d})$ and second $(\mathbf{e}, \mathbf{f})$ type of biogenic calcretes present within marine limestones of the Gornji Humac Formation (Šibenik locality; see Fig. 2) and marking a regional $\mathrm{K}-\mathrm{Pg}$ subaerial unconformity. a Polished slab showing biogenic calcrete with numerous rhizoliths present in bundles (white arrows). Calcrete diagenetically overprints and is in sharp contact (black arrows) with marine limestone. Scale in $\mathrm{cm}$. b Close-up of the encircled area in a showing numerous rhizoliths that represent a root mat. Coin diameter: $1.7 \mathrm{~cm}$. c Photomicrograph showing Microcodium aggregates (Brlek et al. 2014) consisting of multiple and single

layers of isodiametric and slightly elongated brownish and whitish calcite crystals commonly surrounding voids filled with sparite (1 and 2). d Photomicrograph showing biogenic calcrete, developed within bioclastic wackestone (bw), with root tubules characterized by welldeveloped alveolar-septal structure (black arrows). e Polished slab of the second type of biogenic calcrete composed entirely of Microcodium aggregates. $\mathbf{f}$ Photomicrographs of the second type of biogenic calcrete composed of typical single-layered and multilayered $\mathrm{Mi}$ crocodium aggregates (Brlek et al. 2014) 
et al. 2008; Korbar 2009), and were deposited on a carbonate ramp (Ćosović et al. 2004) developing in the most distal parts of foreland basins (Otoničar 2007; Zamagni et al. 2008; Korbar 2009).

\section{Regional K-Pg subaerial unconformity and composite surface}

The Cretaceous to Paleogene $(\mathrm{K}-\mathrm{Pg})$ stratigraphic gap recorded in the study area and in other ADCP Cenomanian to Maastrichtian successions is unconformably overlain by Paleogene transgressive marine deposits (Ćosović et al. 2004; Korbar 2009; Brlek et al. 2013, 2014), and is the consequence of differential and diachronous uplift of several parts of the platform(s), interpreted as forebulging associated with the Dinaric orogeny (Durn et al. 2003; Otoničar 2007; Korbar 2009). This stratigraphic gap is in the order of several My in duration and is commonly marked by well-developed paleokarstic horizons and bauxitic deposits (Šinkovec 1973; Sakač and Šinkovec 1991; Otoničar 2007; Kovačević Galović et al. 2012), which reflect significant environmental changes in response to long-term, regional to global processes of tectono-eustatic origin (Clari et al. 1995; D'Argenio and Mindszenty 1995; Hillgärtner 1998). The regional unconformity at Šibenik (Figs. 1c, 2) (Brlek et al. 2014), on the Island of Čiovo (Fig. 1c) (Brlek et al. 2013), and in the Labin-Koromačno area (Fig. 1d) (Otoničar 2007), lacks typical paleokarst features and bauxite, and is instead characterized by biogenic (beta microfabric) calcretes with rhizoliths, including in situ Microcodium aggregates and root tubules with alveolar-septal structure (Figs. 2, 3) (Brlek et al. 2013, 2014). The Microcodium aggregates are represented by multiple layers of isodiametric calcite crystals as well as typical Microcodium aggregates composed of single layers of elongated calcite crystals (Fig. 3; Brlek et al. 2014). In the Maastrichtian to Paleocene Sumartin Formation on the Island of Hvar, the regional unconformity is also characterized by laminar calcretes and pisoids (partly formed by calcretization of bauxite), as well as typical paleokarst features (including in situ and re-sedimented speleothems) (Brlek et al. 2014; see also Otoničar et al. 2003; Otoničar 2007).

Several intraformational discontinuity surfaces, characterized by well-developed and diagnostic trace fossils and subaerial exposure features, have been also recorded in the Gornji Humac Formation at the Šibenik locality (Fig. 2) (Brlek et al. 2014). Thalassinoides paradoxicus boxworks of the Glossifungites ichnofacies characterize the submarine firmground stage of the composite surface. The rhizogenic laminar calcretes that developed subsequently only inside the burrows of the composite surface, through diagenetic overprinting of the primary marine bioclastic packstones (first generation of the burrow fill) (Figs. 2, 4), indicate that this surface also experienced subaerial exposure (Brlek et al. 2014). Rhizogenic laminar calcretes of horizontal, sub-horizontal, and vertical orientations contain laminated fabric with root tubules and alveolar-septal structure (Fig. 4). Different types of trace fossils recorded in the composite surface may indicate several stages of regression and transgression (Brlek et al. 2014).

\section{Materials and methods}

Calcretes and host marine carbonates, marking the regional K-Pg subaerial unconformity, were sampled in the field for isotope analysis (total of 38 samples; Table 1) at three well-exposed Upper Cretaceous sedimentary sections selected on the basis of previous sedimentological and stratigraphic investigations. These included the Šibenik locality (Figs. 1c, 2), the Island of Čiovo (Fig. 1c) (central Dalmatia, Croatia; Brlek et al. 2013, 2014), and the LabinKoromačno area (eastern Istria; Fig. 1d). Isotopic analysis of calcretes was performed on 29 samples of various types of calcretes characterized by specific components (see "Results"; Table 1), as well as on nine samples of host marine carbonate (Table 1). Calcrete and host marine carbonate samples from the Upper Cretaceous intraformational composite surface were collected at the Šibenik locality (Figs. 1c, 2), with isotopic analysis carried out on 17 samples (Table 2). The calcrete samples (total of eight) proved to be highly heterogeneous in composition. This heterogeneity was also observed in petrographic thinsections (see "Results"; Table 2), and it could not be excluded that in these samples some associated marine carbonate (bioclastic packstone sediment) was also present.

For stable isotope analysis, a small amount of carbonate powder was collected from polished slabs and thin-section billets using a microdrill mounted on a binocular microscope. All samples were heated at $400{ }^{\circ} \mathrm{C}$ for $1 \mathrm{~h}$ to remove volatile organic components. Samples were then reacted with $100 \%$ anhydrous phosphoric acid $\left(\mathrm{H}_{3} \mathrm{PO}_{4}\right)$ for $5 \mathrm{~min}$ and analyzed using an on-line automated carbonate preparation system (Kiell III) linked to a FinniganMAT DeltaXL + ratio mass spectrometer at the University of Massachusetts, Amherst, USA. Standard isobaric and phosphoric acid fractionation corrections were applied to all data. Internal analytical precision, monitored through daily analysis of carbonate standards, is better than or equal to $0.1 \%$ for both carbon and oxygen isotope values. Stable isotope results are expressed as $\delta^{13} \mathrm{C}$ and $\delta^{18} \mathrm{O}$ values in \%o relative to the Vienna PeeDee Belemnite standard (VPDB). 

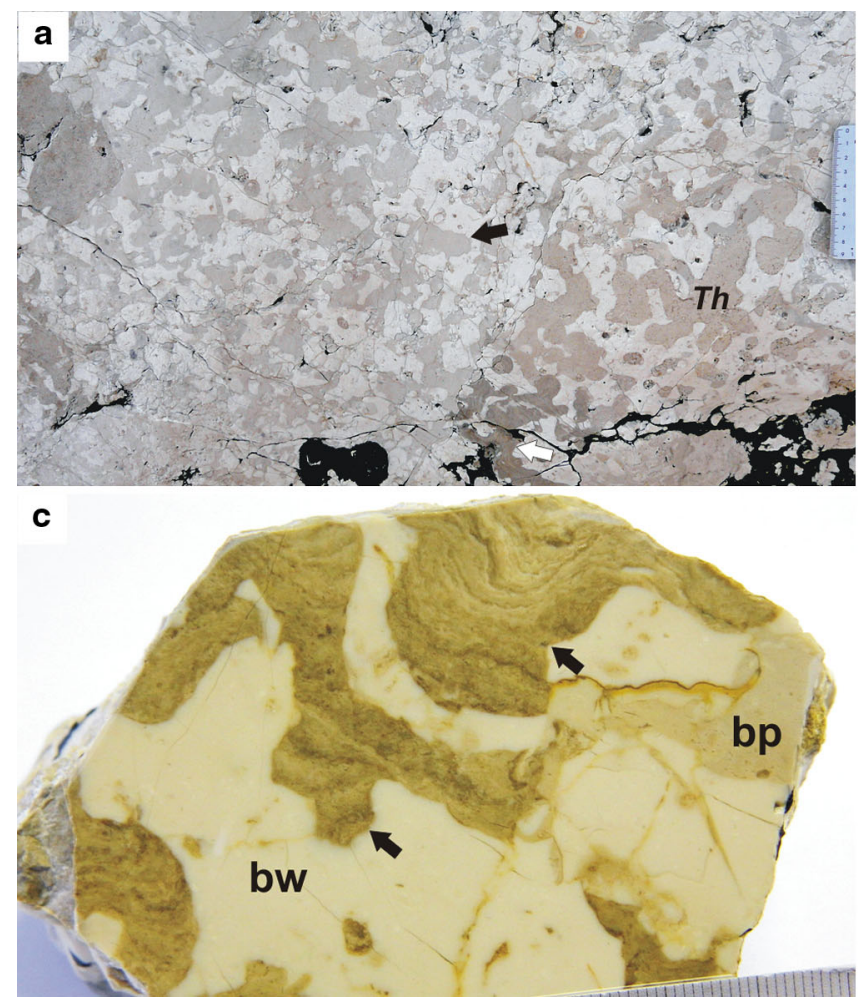

Fig. 4 Characteristics of the composite surface recorded in the Gornji Humac Formation (Šibenik locality; see Fig. 2). a Bedding plane view of the composite surface penetrated by well-developed three-dimensional branching and box-work Thalassinoides (Th). The burrows are filled with marine sediment (light grey, black arrow), as well as by rhizogenic calcrete (dark grey, white arrow). b Bedding plane view of Thalassinoides filled with laminated calcrete (black arrow). Coin diameter is $2.2 \mathrm{~cm}$. c Polished slab representing vertical

\section{Results}

Stable isotope geochemistry of biogenic calcretes and host rocks marking the regional $\mathrm{K}-\mathrm{Pg}$ subaerial unconformity

Calcretes marking the regional subaerial unconformity in the Gornji Humac (Šibenik locality) and Čiovo formations (Island of Čiovo), as well as in the Upper Cretaceous carbonates of eastern Istria (Labin-Koromačno area) have been analyzed and compared to the host rocks with respect to both petrography (Fig. 3; see Brlek et al. 2013, 2014) and stable isotope geochemistry (Table 1; Figs. 5, 6). While the stable carbon isotopic composition of the calcretes differ significantly (i.e., calcrete have more negative $\delta^{13} \mathrm{C}$ values) from that of the host rocks (Table 1; Figs. 5, $6)$, the oxygen isotope compositions show less difference (Table 1; Figs. 5, 6).

In the Gornji Humac Formation, the $\delta^{13} \mathrm{C}$ and $\delta^{18} \mathrm{O}$ values of the first type of biogenic calcretes (Brlek et al. 2014) with rhizoliths, including Microcodium aggregates,
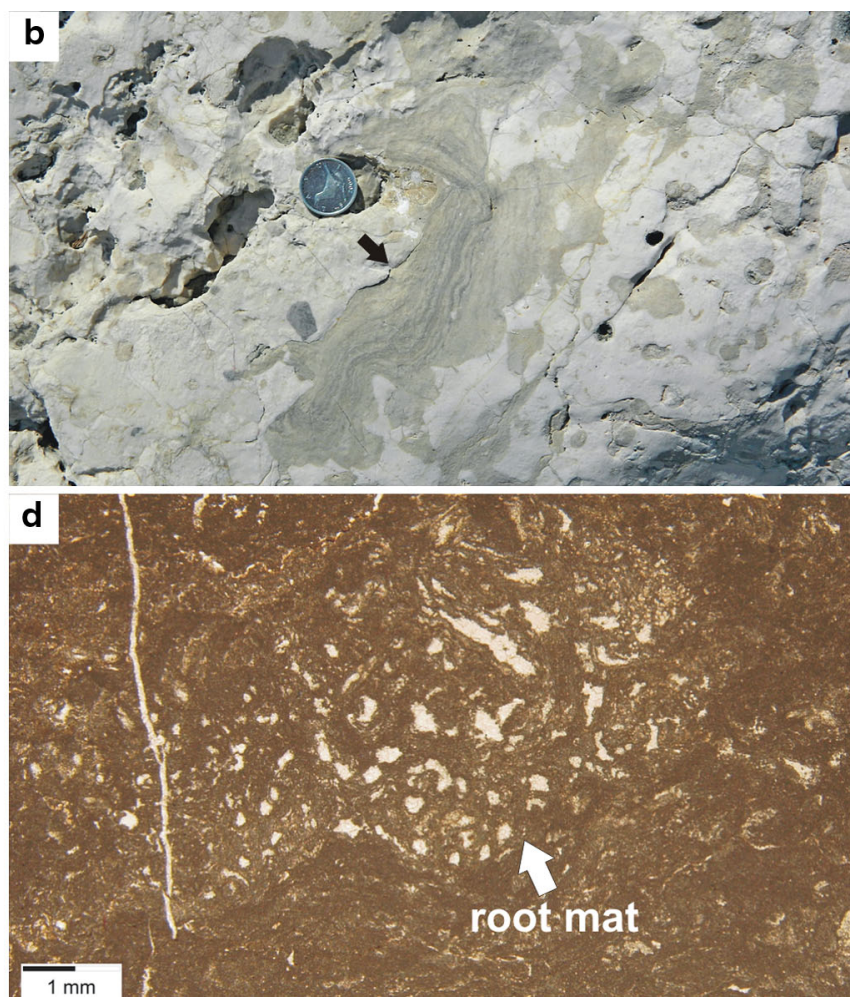

section of irregularly branching Thalassinoides burrow systems in which laminar rhizogenic calcretes (black arrows) occur inside the burrows intercalated with bioclastic packstone (bp), which they diagenetically overprint. The burrows were mainly made in bioclastic wackestone (bw). d Photomicrograph of laminar rhizogenic calcrete developed inside Thalassinoides burrows and composed of root tubules

as well as with alveolar-septal structure and pedogenic micrite (Figs. 3a-d, 6a) (ŠMA-PK4 t1; 6 samples), range from -10.5 to $-8.2 \%$ VPDB (average $\delta^{13} \mathrm{C}$ value $-9.6 \%$ VPDB) and from -8.4 to $-6.8 \%$ VPDB (average $\delta^{18} \mathrm{O}$ value $-7.6 \%$ VPDB), respectively (Table 1; Figs. 5, $6 a)$. The $\delta^{13} \mathrm{C}$ and $\delta^{18} \mathrm{O}$ values of the second type of biogenic calcretes (Brlek et al. 2014) with typical Microcodium aggregates (Figs. 3e, f, 6b) (ŠMA-PK4 t2; 6 samples) range from -13.1 to $-12.3 \%$ VPDB (average $\delta^{13} \mathrm{C}$ value $-12.7 \%$ VPDB) and from -9.1 to $-8.4 \%$ VPDB (average $\delta^{18} \mathrm{O}$ value $-8.8 \%$ VPDB), respectively (Table 1; Figs. 5, 6b). In contrast, the $\delta^{13} \mathrm{C}$ and $\delta^{18} \mathrm{O}$ values of the marine host rock (ŠMA-PK4 ms; 5 samples) at the same locality range from -5.3 to $-3.7 \%$ VPDB (average $\delta^{13} \mathrm{C}$ value $-4.4 \%$ VPDB) and from -6.5 to $-6.1 \%$ VPDB (average $\delta^{18} \mathrm{O}$ value $-6.3 \%$ VPDB), respectively (Table 1; Figs. 5, 6a). In the Ćiovo Formation, the $\delta^{13} \mathrm{C}$ and $\delta^{18} \mathrm{O}$ values of biogenic calcretes with typical $M i$ crocodium aggregates (Brlek et al. 2013) (ČKT Mc; 4 samples) range from -9.3 to $-8.2 \%$ VPDB (average $\delta^{13} \mathrm{C}$ value $-8.7 \%$ VPDB) and from -7.7 to $-6.3 \%$ VPDB 
Table $1 \delta^{13} \mathrm{C}$ and $\delta^{18} \mathrm{O}$ values of 38 samples of biogenic calcretes and marine host carbonates marking the regional $\mathrm{K}-\mathrm{Pg}$ subaerial unconformity in the Upper Cretaceous carbonates of central Dalmatia and eastern Istria, Croatia

\begin{tabular}{|c|c|c|c|}
\hline Sample name & Sample description & $\delta^{13} \mathrm{C}(\%, \mathrm{VPDB})$ & $\delta^{18} \mathrm{O}(\%, \mathrm{VPDB})$ \\
\hline \multicolumn{4}{|c|}{$\mathrm{K}-\mathrm{Pg}$ unconformity } \\
\hline \multicolumn{4}{|c|}{ Šibenik, Gornji Humac Fm } \\
\hline ŠMA-PK4 t1 1 & Type 1 beta calcrete with predominant rh and $M c$ & -8.3 & -6.8 \\
\hline ŠMA-PK4 t1 2 & Type 1 beta calcrete with predominant rh and $M c$ & -10.5 & -8.1 \\
\hline ŠMA-PK4 t1 3 & Type 1 beta calcrete with predominant rh and $M c$ & -8.2 & -7.1 \\
\hline ŠMA-PK4 t1 4 & Type 1 beta calcrete with rh, alv.-sept. str., micrite & -10.4 & -7.7 \\
\hline ŠMA-PK4 t1 5 & Type 1 beta calcrete with rh, alv.-sept. str., micrite & -10.2 & -7.7 \\
\hline ŠMA-PK4 t1 6 & Type 1 beta calcrete with rh, alv.-sept. str., micrite & -10.1 & -8.4 \\
\hline Range & & -10.5 to -8.2 & -8.4 to -6.8 \\
\hline Average value & & -9.6 & -7.6 \\
\hline ŠMA-PK4 t2 1 & Type 2 beta calcrete with typical $M c$ & -12.6 & -9.1 \\
\hline ŠMA-PK4 t2 2 & Type 2 beta calcrete with typical $M c$ & -12.5 & -8.7 \\
\hline ŠMA-PK4 t2 3 & Type 2 beta calcrete with typical $M c$ & -13.1 & -8.4 \\
\hline ŠMA-PK4 t2 4 & Type 2 beta calcrete with typical $M c$ & -12.3 & -8.9 \\
\hline ŠMA-PK4 t2 5 & Type 2 beta calcrete with typical $M c$ & -13 & -8.8 \\
\hline ŠMA-PK4 t2 6 & Type 2 beta calcrete with typical $M c$ & -12.5 & -8.6 \\
\hline Range & & -13.1 to -12.3 & -9.1 to -8.4 \\
\hline Average value & & -12.7 & -8.8 \\
\hline ŠMA-PK4 ms 1 & Shallow-marine limestone & -5.3 & -6.3 \\
\hline ŠMA-PK4 ms 2 & Shallow-marine limestone & -3.7 & -6.1 \\
\hline ŠMA-PK4 ms 3 & Shallow-marine limestone & -4.6 & -6.1 \\
\hline ŠMA-PK4 ms 4 & Shallow-marine limestone & -4 & -6.4 \\
\hline ŠMA-PK4 ms 5 & Shallow-marine limestone & -4.6 & -6.5 \\
\hline Range & & -5.3 to -3.7 & -6.5 to -6.1 \\
\hline Average value & & -4.4 & -6.3 \\
\hline \multicolumn{4}{|c|}{ Island of Čiovo, Čiovo Fm } \\
\hline ČKT Mc 1 & Beta calcrete with typical $M c$ & -9.3 & -7.1 \\
\hline ČKT Mc 2 & Beta calcrete with typical $M c$ & -8.3 & -6.3 \\
\hline ČKT Mc 3 & Beta calcrete with typical $M c$ & -9 & -7.2 \\
\hline ČKT Mc 4 & Beta calcrete with typical $M c$ & -8.2 & -7.7 \\
\hline Range & & -9.3 to -8.2 & -7.7 to -6.3 \\
\hline Average value & & -8.7 & -7.1 \\
\hline ČKT ms 1 & Marine bioclastic packstone & -6.2 & -6.6 \\
\hline ČKT ms 2 & Marine bioclastic packstone & -6 & -6.5 \\
\hline ČKT ms 3 & Marine bioclastic packstone & -6.5 & -6.6 \\
\hline ČKT ms 4 & Marine bioclastic packstone & -7 & -7.1 \\
\hline Range & & -7 to -6 & -7.1 to -6.5 \\
\hline Average value & & -6.4 & -6.7 \\
\hline \multicolumn{4}{|c|}{ Labin-Koromačno area, Upper Cretac. } \\
\hline SAW5 K2 1 & Beta calcrete with typical $M c$ & -10.4 & -7.5 \\
\hline SAW5 K2 2 & Beta calcrete with typical $M c$ & -9.5 & -9 \\
\hline SAW5 K2 4 & Beta calcrete with typical $M c$ & -9.7 & -9.2 \\
\hline SAW5 K2 5 & Beta calcrete with typical $M c$ & -9.4 & -9.1 \\
\hline SAW5 K2 6 & Beta calcrete with typical $M c$ & -9.1 & -9 \\
\hline SAW5 K2 8 & Beta calcrete with typical $M c$ & -9.5 & -8.8 \\
\hline SAW5 K2 10 & Beta calcrete with typical $M c$ & -10.4 & -9 \\
\hline SAW5 K2 12 & Beta calcrete with typical $M c$ & -9.5 & -8.6 \\
\hline SAW5 K2 13 & Beta calcrete with typical $M c$ & -9.1 & -9.1 \\
\hline
\end{tabular}


Table 1 continued

\begin{tabular}{llll}
\hline Sample name & Sample description & $\delta^{13} \mathrm{C}(\% \mathbf{0}, \mathrm{VPDB})$ & $\delta^{18} \mathrm{O}(\% \mathbf{0}, \mathrm{VPDB})$ \\
\hline SAW5 K2 14 & Beta calcrete with typical $M c$ & -8.4 & -8.1 \\
SAW5 K2 15 & Beta calcrete with typical $M c$ & -8.7 & -9.4 \\
SAW5 K2 A & Beta calcrete with typical $M c$ & -8.3 & -10.1 \\
SAW5 P1 B & Beta calcrete with typical $M c$ & -8.2 & -10 \\
Range & & -10.4 to -8.2 & -10.1 to -7.5 \\
Average value & & -9.3 & -9 \\
\hline
\end{tabular}

Fm, formation; Cretac., Cretaceous; rh, rhizoliths; Mc, Microcodium; alv.-sept. str., alveolar-septal structure

Table $2 \delta^{13} \mathrm{C}$ and $\delta^{18} \mathrm{O}$ values of 17 samples of biogenic calcretes and marine host carbonates marking the composite surface in the Upper Cretaceous carbonates of central Dalmatia (Šibenik locality, Croatia)

\begin{tabular}{|c|c|c|c|}
\hline Sample name & Sample description & $\delta^{13} \mathrm{C}(\%, \mathrm{VPDB})$ & $\delta^{18} \mathrm{O}(\%, \mathrm{VPDB})$ \\
\hline \multicolumn{4}{|l|}{ Composite surface } \\
\hline \multicolumn{4}{|c|}{ Šibenik, Gornji Humac Fm } \\
\hline ŠMA-27 Th rzc 1 & Rhizogenic laminar calcrete (bpi) inside $T h$ & -4 & -6.4 \\
\hline ŠMA-27 Th rzc 2 & Rhizogenic laminar calcrete (bpi) inside $T h$ & -4 & -7 \\
\hline ŠMA-27 Th rzc 3 & Rhizogenic laminar calcrete (bpi) inside $T h$ & -3.6 & -6.2 \\
\hline ŠMA-27 Th rzc 4 & Rhizogenic laminar calcrete (bpi) inside $T h$ & -4.2 & -5.8 \\
\hline ŠMA-27 Th rzc 5 & Rhizogenic massive calcrete (bpi) inside $T h$ & -4.4 & -6.4 \\
\hline ŠMA-27 Th rzc 6 & Rhizogenic massive calcrete (bpi) inside $T h$ & -4.1 & -6.5 \\
\hline ŠMA-27 Th rzc 7 & Rhizogenic massive calcrete (bpi) inside $T h$ & -4.3 & -6.6 \\
\hline ŠMA-27 Th rzc 8 & Rhizogenic massive calcrete (bpi) inside $T h$ & -4.3 & -6.3 \\
\hline Range & & -4.4 to -3.6 & -7 to -5.8 \\
\hline Average value & & -4.1 & -6.4 \\
\hline ŠMA-27 Th bp 1 & Bioclastic packstone inside $T h$ & -2.8 & -5.6 \\
\hline ŠMA-27 Th bp 2 & Bioclastic packstone inside $T h$ & -2.9 & -6 \\
\hline ŠMA-27 Th bp 3 & Bioclastic packstone inside $T h$ & -2.2 & -4.7 \\
\hline ŠMA-27 Th bp 4 & Bioclastic packstone inside $T h$ & -2.6 & -5.8 \\
\hline Range & & -2.9 to -2.2 & -5.8 to -4.7 \\
\hline Average value & & -2.6 & -5.5 \\
\hline ŠMA-27 ms 1 & Host bioclastic wackestone & -3.1 & -5.9 \\
\hline ŠMA-27 ms 2 & Host bioclastic wackestone & -2.8 & -5.4 \\
\hline ŠMA-27 ms 3 & Host bioclastic wackestone & -2.9 & -6.5 \\
\hline ŠMA-27 ms 4 & Host bioclastic wackestone & -3.1 & -6.1 \\
\hline ŠMA-27 ms 5 & Host bioclastic wackestone & -3.2 & -7 \\
\hline Range & & -3.2 to -2.8 & -7 to -5.4 \\
\hline Average value & & -3 & -6.2 \\
\hline
\end{tabular}

Fm, formation; Th, Thalassinoides; bpi, bioclastic packstone intercalation

(average $\delta^{18} \mathrm{O}$ value $-7.1 \%$ VPDB), respectively (Table 1; Figs. 5, 6c), while the $\delta^{13} \mathrm{C}$ and $\delta^{18} \mathrm{O}$ values of marine host bioclastic packstone (ČKT ms; 4 samples) range from -7 to $-6 \%$ VPDB (average $\delta^{13} \mathrm{C}$ value $-6.4 \%$ VPDB) and from -7.1 to $-6.5 \%$ VPDB (average $\delta^{18} \mathrm{O}$ value of $-6.7 \%$ VPDB), respectively (Table 1 ; Fig. 5). In the Upper Cretaceous carbonates of the LabinKoromačno area, the $\delta^{13} \mathrm{C}$ and $\delta^{18} \mathrm{O}$ values of biogenic calcretes with typical Microcodium aggregates (SAW5; 13 samples) have a range from -10.4 to $-8.2 \%$ VPDB (average $\delta^{13} \mathrm{C}$ value $-9.3 \%$ VPDB) and from -10.1 to $-7.5 \%$ VPDB (average $\delta^{18} \mathrm{O}$ value $-9 \%$ VPDB), respectively (Table 1; Figs. 5, 6d).

Stable isotope geochemistry of biogenic calcretes and host rocks marking the composite surface

Isotopic composition of rhizogenic calcretes that developed within firmground Thalassinoides burrows and diagenetically overprinted marine deposits (first generation of 


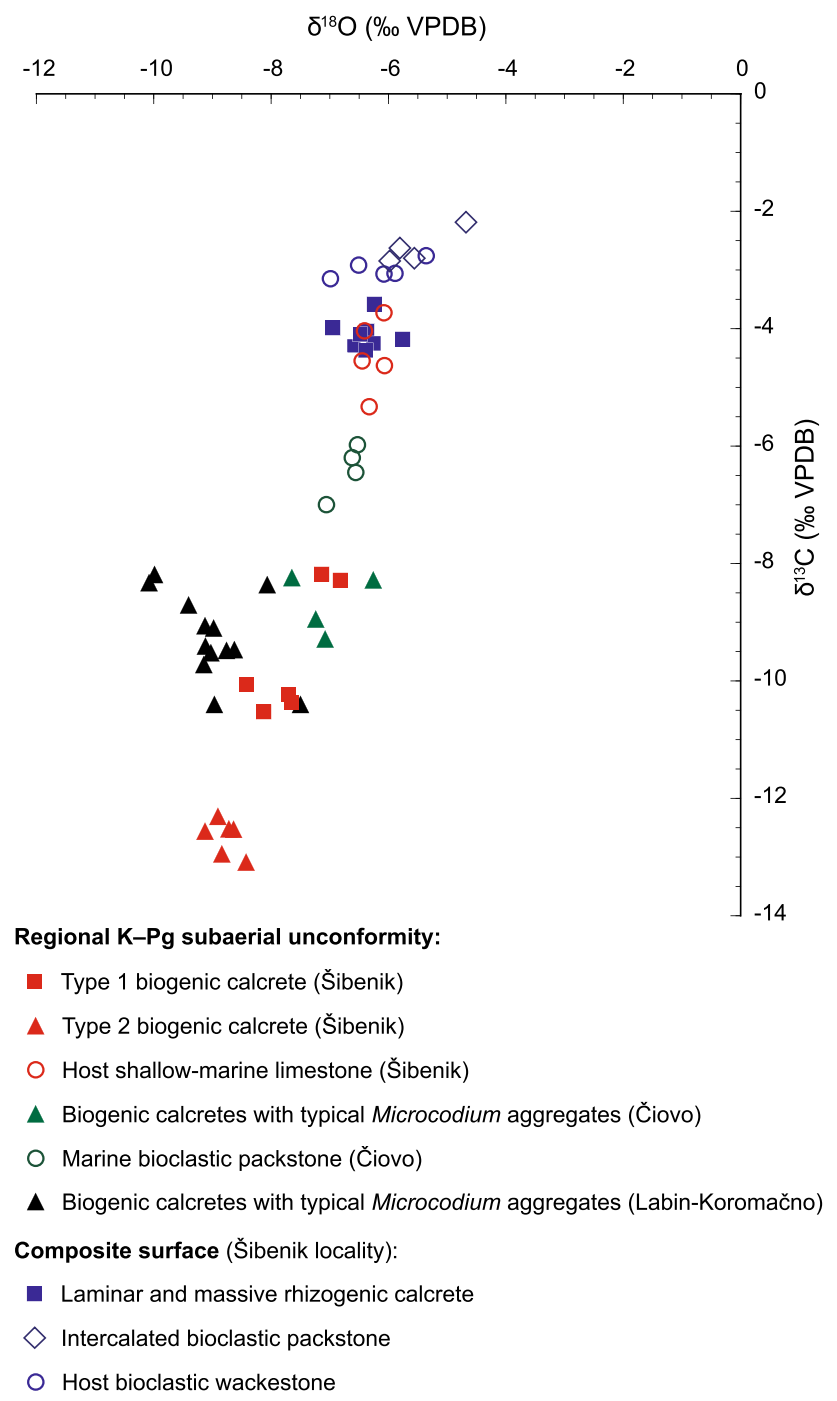

Fig. $5 \delta^{13} \mathrm{C}-\delta^{18} \mathrm{O}$ cross-plot of biogenic calcretes and marine host rocks associated with regional $\mathrm{K}-\mathrm{Pg}$ subaerial unconformity and composite surface from the studied Upper Cretaceous localities, with accompanying legend (see Tables 1, 2 and text for explanation)

burrow fill) of an intraformational composite surface (Brlek et al. 2014), as well as isotopic composition of the marine host rocks from the Gornji Humac Formation (Šibenik locality), were also analyzed in this study (Table 2; Figs. 4, 5, 6). Although the carbon isotopic composition of the calcretes is more negative than that of the host rocks (Table 2; Figs. 5, 6), it shows a less profound difference from the host rock in comparison to calcretes associated with the regional subaerial unconformity (Table 1; Figs. 5, 6). In addition, there is even less difference in oxygen isotope composition between calcretes from the intraformational composite surface and the host rock (Table 2; Figs. 5, 6).

The $\delta^{13} \mathrm{C}$ and $\delta^{18} \mathrm{O}$ values of rhizogenic (root tubules and alveolar-septal structures) laminar and more massive
Fig. $6 \delta^{13} \mathrm{C}$ and $\delta^{18} \mathrm{O}$ values in \%o relative to the Vienna PeeDee Belemnite standard (VPDB) of selected biogenic calcrete and host marine carbonate samples (Tables 1, 2; Fig. 5; see text), from the regional K-Pg subaerial unconformity (a-d) and intraformational composite surface $(\mathbf{e}, \mathbf{f})$. First (a) and second (b) type of biogenic calcrete at the Šibenik locality. Biogenic calcretes with typical Microcodium aggregates at the Ciovo (c) and Labin-Koromačno (d) localities. Firmground Thalassinoides burrows of the composite surface (Šibenik locality) filled with laminar (e) and massive (f) rhizogenic calcrete, with intercalated bioclastic packstone (e). Symbols as in Fig. 5

calcretes characterized by heterogeneous composition due to intercalations of marine bioclastic packstone (Table 2; Figs. 4, 6) (ŠMA-27 Th rzc; 8 samples) range from -4.4 to $-3.6 \%$ VPDB (average $\delta^{13} \mathrm{C}$ value $-4.1 \%$ VPDB) and from -7 to $-5.8 \%$ VPDB (average $\delta^{18} \mathrm{O}$ value $-6.4 \%$ VPDB), respectively (Table 2; Figs. 5, 6e, f). The $\delta^{13} \mathrm{C}$ and $\delta^{18} \mathrm{O}$ values of bioclastic packstone (ŠMA-27 Th bp; 4 samples), which represents the first generation of marine firmground burrow fill, range from -2.9 to $-2.2 \%$ VPDB (average $\delta^{13} \mathrm{C}$ value $-2.6 \%$ VPDB) and from -5.8 to $-4.7 \%$ VPDB (average $\delta^{18} \mathrm{O}$ value $-5.5 \%$ VPDB), respectively (Table 2; Figs. 5, 6e), while the $\delta^{13} \mathrm{C}$ and $\delta^{18} \mathrm{O}$ values of bioclastic wackestone (ŠMA-27 ms; 5 samples), on which the composite surface developed range from -3.2 to $-2.8 \%$ VPDB (average $\delta^{13} \mathrm{C}$ value $-3 \%$ VPDB) and from -7 to $-5.4 \%$ VPDB (average $\delta^{18} \mathrm{O}$ value $-6.2 \%$ VPDB), respectively (Table 2; Figs. 5, 6f).

\section{Discussion}

Interpretation of $\delta^{13} \mathrm{C}$ and $\delta^{18} \mathrm{O}$ values of biogenic calcretes and host rocks marking the regional $\mathrm{K}-\mathrm{Pg}$ subaerial unconformity

Distinctly negative $\delta^{13} \mathrm{C}$ values and to a lesser extent negative $\delta^{18} \mathrm{O}$ values of biogenic calcretes (Table 1; Figs. 5, 6) marking the regional $\mathrm{K}-\mathrm{Pg}$ subaerial unconformity, are used as a tool for recognition of meteoric pedo(dia)genesis of primary marine Upper Cretaceous carbonate deposits. The negative $\delta^{13} \mathrm{C}$ values, which differ significantly from carbon isotopic signatures of primary marine limestones (Table 1; Figs. 5, 6), reflect carbon isotope exchange of primary marine $\mathrm{CaCO}_{3}$ with $\mathrm{CO}_{2}$ released by root and rhizomicrobial respiration and subsequent precipitation of pedogenic calcrete (Cerling 1984; Gocke 2010). In addition, the stable isotopic signatures and trends of primary marine limestones at the Šibenik locality and on the Island of Čiovoalso indicate their meteoric diagenetic overprint (cf. Allan and Matthews 1982; James and Choquette 1990; Rossinsky et al. 1993; Li and Jones 2014). The $\delta^{13} \mathrm{C}$ values of marine limestones with an 

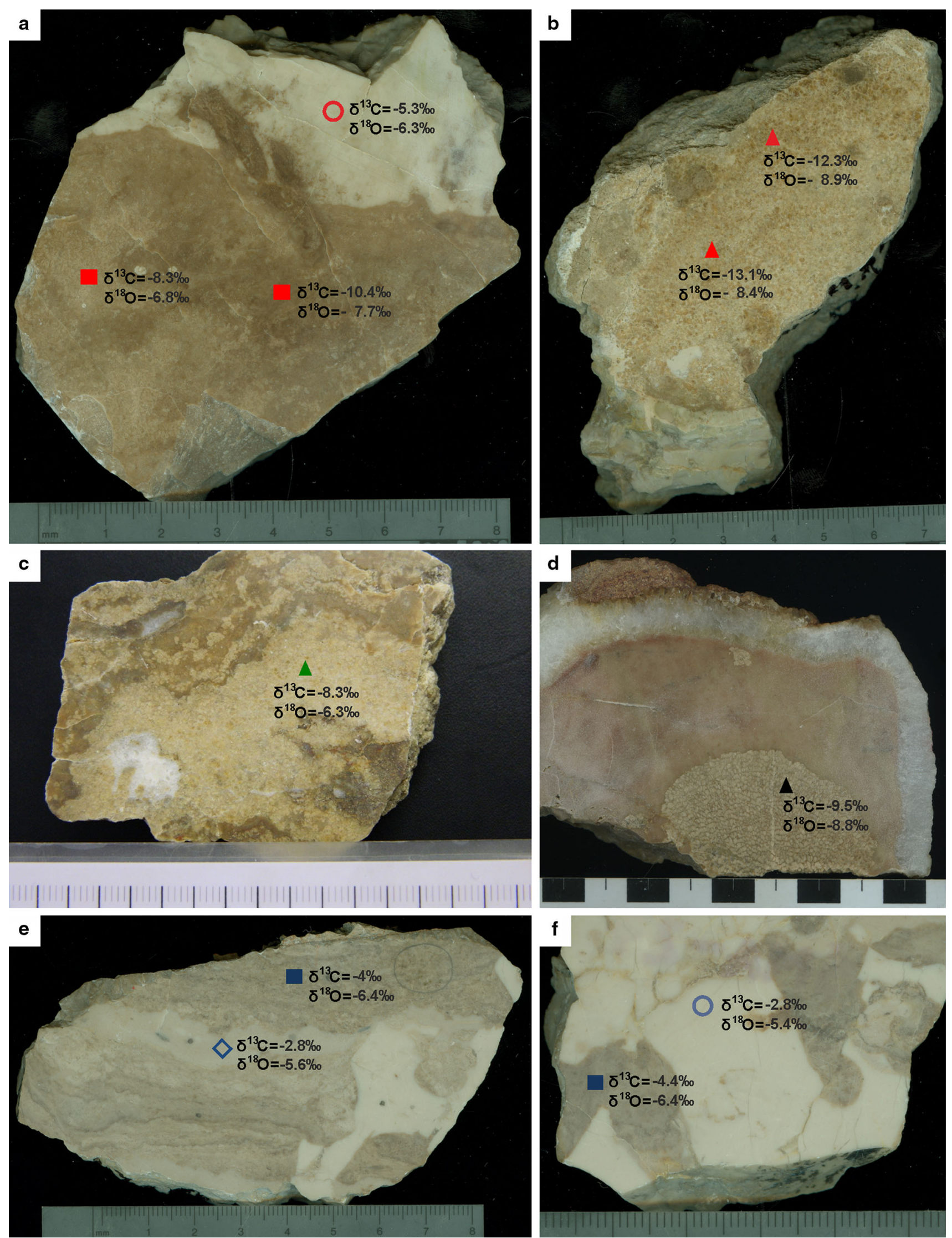
average value of $-4.5 \%$ VPDB (Šibenik locality) and $-6.4 \%$ VPDB (Island of Čiovo) (Table 1; Figs. 5, 6) result from pedo(dia)genetic processes (carbon isotope exchange processes; see above) during vadose meteoric diagenesis (Allan and Matthews 1982; James and Choquette 1990; Rossinsky et al. 1993; Li and Jones 2014). In addition, the $\delta^{13} \mathrm{C}$ values of limestones from the upper part of the subaerially exposed horizon at the Šibenik locality are more negative than those of marine deposits associated with the composite surface (average value of $-3 \%$ VPDB) (Table 2; Fig. 5), which is located about $30 \mathrm{~m}$ below the regional subaerial exposure surface (Fig. 2). Although this could indicate a trend of increasing $\delta^{13} \mathrm{C}$ values of the host marine limestone with increasing depth, which represents a common feature in subaerially exposed marine successions (the "inverted J" trend; Allan and Matthews 1982; Lohmann 1988; James and Choquette 1990), a more detailed analysis of stratigraphic variation of $\delta^{13} \mathrm{C}$ values of the host limestone would be required in order to reach a definite conclusion.

Secondary authigenic carbonates in soils and paleosoils are mostly interpreted to have formed in isotopic equilibrium with soil $\mathrm{CO}_{2}$ (Cerling 1984, 1999), which derives mainly from root respiration and microbial decomposition of soil organic matter (Amundson et al. 1998; Gocke et al. 2011a). The metabolic pathway of vegetation (e.g., $C_{3}$ and $\mathrm{C}_{4}$ plants) has an influence on carbon isotopic composition of soil $\mathrm{CO}_{2}$, which in turn affects the carbon isotopic signal of secondary carbonates (Cerling 1984, 1999; Burns and Rossinsky 1989; Gocke 2010). Therefore, $\delta^{13} \mathrm{C}$ (together with $\delta^{18} \mathrm{O}$ ) compositions of pedogenic carbonates may be useful in reconstructing paleo-vegetation (e.g., $\mathrm{C}_{3} / \mathrm{C}_{4}$ plant ratio) and paleoclimatic conditions, including paleotemperature, paleo-precipitation, moisture conditions and atmospheric $p \mathrm{CO}_{2}$ in arid and semiarid environments (Cerling 1984, 1999; Gocke et al. 2011a; Koeniger et al. 2014). Radiocarbon dating of pedogenic carbonates also proved useful in determining age of pedogenesis and sediments in Quaternary deposits (e.g., Pustovoytov et al. 2007; Gocke et al. 2011a). The basic prerequisite for such paleoenvironmental and geochronological studies interpreting isotope composition of pedogenic carbonates is the long-term preservation of the isotopic signal, which was incorporated in pedogenic carbonates during their formation (Gocke et al. 2011a). The $\delta^{13} \mathrm{C}$ and $\delta^{18} \mathrm{O}$ values of all calcrete types analyzed here, ranging from -13.1 to $-8.2 \%$ VPDB and from -10.1 to $-6.1 \%$ VPDB respectively (Table 1; Fig. 5), are similar to those reported from calcretes elsewhere (Talma and Netterberg 1983; Cerling 1984; Salomons and Mook 1986; Alonso-Zarza 2003). The $\delta^{13} \mathrm{C}$ values are also within the range of calcretes recorded in Recent and Pleistocene subaerially exposed carbonate profiles $\left(\delta^{13} \mathrm{C}\right.$ from -13 to $-7 \%$ PDB;
James and Choquette 1990). As in other examples, the variations in $\delta^{13} \mathrm{C}$ are slightly greater than those in $\delta^{18} \mathrm{O}$ (Talma and Netterberg 1983; Alonso-Zarza 2003; AlonsoZarza and Arenas 2004; Li and Jones 2014), with the $\delta^{18} \mathrm{O}$ values of calcretes (Table 1; Figs. 5, 6) reflecting formation under the influence of meteoric water (Wright and Tucker 1991; Alonso-Zarza 2003; Gocke 2010). In all calcrete types analyzed here, and especially in the second type of biogenic calcretes with typical Microcodium aggregates (Brlek et al. 2014) from the Gornji Humac Formation with $\delta^{13} \mathrm{C}$ values from -13.1 to $-12.3 \%$ VPDB (average value $-12.7 \%$ ) (Table 1; Fig. 5), the values of $\delta^{13} \mathrm{C}$ (Table 1; Fig. 5) are very close to, or are at the lower limit of, values of -12 to $-13 \%$ PDB for soil carbonates formed in isotopic equilibrium with soil $\mathrm{CO}_{2}$ (Cerling 1984, 1999; Burns and Rossinsky 1989). Such very negative values are expected for authigenic pedogenic carbonates formed under the influence of $100 \%$ of $\mathrm{C}_{3}$ plant communities (most plants, including trees, shrubs, forbs and cool/shade grasses), whose metabolism follows the Calvin pathway, and without any input of heavier carbon from pre-existing carbonate deposits or from atmospheric $\mathrm{CO}_{2}$ (Alonso-Zarza et al. 1998; Alonso-Zarza 1999; Deocampo 2010; Tanner 2010). An average $\delta^{13} \mathrm{C}$ value of $\mathrm{C}_{3}$ plant communities is $-27 \%$ PDB, with the lower limit of carbon isotope values recorded in pedogenic carbonates analyzed here (Table 1; Figs. 5, 6) resulting from isotope discrimination by $4.4 \%$ due to $\mathrm{CO}_{2}$ diffusion and from further discrimination by about $10.5 \%$ due to carbonate equilibrium reactions (Cerling 1984, 1999; Burns and Rossinsky 1989; Gocke 2010). The absence of $\mathrm{C}_{4}$ plant communities (see Bajnóczi and Kovács-Kis 2006; Wang and Greenberg 2007; Zhou and Chafetz 2009a) in the paleoenvironment studied here is in agreement with the Late Cretaceous to Paleogene (Eocene) age span of calcrete development (Brlek et al. 2013, 2014 and references therein), and the absence of $\mathrm{C}_{4}$ vegetation prior to the Neogene (Cerling 1999; Alonso-Zarza and Arenas 2004; Tanner 2010). $\delta^{13} \mathrm{C}$ values as low as in this study may suggest precipitation of pedogenic carbonate under direct biological control within the soil (Alonso-Zarza et al. 1998; Alonso-Zarza 1999). This is evident in examples of $\mathrm{Mi}$ crocodium aggregates (Brlek et al. 2013, 2014), whose formation is most commonly interpreted as biologically controlled precipitation of calcium carbonate in cortical plant root cells (i.e., intracellular calcification; Wright et al. 1995; Alonso-Zarza et al. 1998; see also Klappa 1980; Jaillard et al. 1991) and subjected to subsequent morphological transformations (Košir 2004; Brlek et al. 2014). Although the $\delta^{13} \mathrm{C}$ values of Microcodium aggregates recorded here fall within the range of values for pedogenic carbonates formed in isotopic equilibrium with soil $\mathrm{CO}_{2}$ (Cerling 1984, 1999; Burns and Rossinsky 1989; Gocke 
2010), there may be other formation mechanisms of $M i$ crocodium and calcified root cells. These include calcite precipitation directly in the plant root cells from solutions containing organic compounds (Łacka et al. 2009; Koeniger et al. 2014) or metabolic activity of rhizosphere bacteria, microbes and fungi (Kabanov et al. 2008; Koeniger et al. 2014; see also Lambers et al. 2009; Zhou and Chafetz $2009 \mathrm{~b}$ ). The influence of these processes may be reflected (among other characteristics) in carbon isotope values of pedogenic carbonates that exceed the lower limit values for soil carbonates formed in isotopic equilibrium with soil $\mathrm{CO}_{2}$ (Kabanov et al. 2008). Clearly, the exact mechanisms of Microcodium formation (as well as other pedogenic carbonates; see Bajnóczi and Kovács-Kis 2006; Milliere et al. 2011) and their influence on carbon and oxygen isotope signatures are still a matter of debate (e.g., Košir 2004; Kabanov et al. 2008).

Interpretation of $\delta^{13} \mathrm{C}$ and $\delta^{18} \mathrm{O}$ values of biogenic calcretes and host rocks marking the composite surface

The $\delta^{13} \mathrm{C}$ values of rhizogenic calcretes inside Thalassinoides burrows that range from -4.4 to $-3.6 \%$ VPDB (average $\delta^{13} \mathrm{C}$ value $-4.1 \%$ VPDB) (Table 2; Figs. 5, 6) are more negative than those of the host marine bioclastic packstone, the latter representing the first generation of Thalassinoides burrow infill (Brlek et al. 2014), and those of the surrounding host marine bioclastic wackestone (Table 2; Figs. 5, 6). Such lower carbon isotope values indicate carbon isotope exchange of primary marine $\mathrm{CaCO}_{3}$ with $\mathrm{CO}_{2}$ released by root and rhizomicrobial respiration and subsequent precipitation of pedogenic calcrete (Cerling 1984; Gocke 2010). This confirms that the composite surface went through a phase of vadose meteoric diagenesis (with development of rhizogenic calcrete that diagenetically overprinted primary marine bioclastic packstone inside Thalassinoides burrows) of a marine firmground (Brlek et al. 2014). However, the overall $\delta^{13} \mathrm{C}$ values of calcretes are less negative than those expected to have formed under conditions of prevailing $\mathrm{C}_{3}$ plant communities (Cerling 1984; Burns and Rossinsky 1989; Alonso-Zarza et al. 1998; Gocke 2010), and are commonly recorded in subaerially exposed carbonate profiles (James and Choquette 1990). Based on the fact that there is no evidence for $\mathrm{C}_{4}$ plant communities prior to the Neogene (Cerling 1999; Alonso-Zarza and Arenas 2004; Tanner 2010), which could have been responsible for higher $\delta^{13} \mathrm{C}$ values in calcretes (see Bajnóczi and Kovács-Kis 2006; Wang and Greenberg 2007; Zhou and Chafetz 2009a), and on the assumptions that carbon isotope composition of calcretes was not influenced by any major input of atmospheric $\mathrm{CO}_{2}$ or by later diagenetic alteration (Zhou and Chafetz 2010; Tanner 2010; Gocke et al. 2011a; Li and
Jones 2014), we suggest that the less negative carbon isotope composition recorded in the analyzed bulk calcrete samples may be a consequence of contamination with $\delta^{13} \mathrm{C}$ signatures from primary marine carbonate (partial pedogenic isotopic signal; Michel et al. 2013; Alonso-Zarza 2003; Bajnóczi and Kovács-Kis 2006; Kraimer and Monger 2009; Zhou and Chafetz 2010). This is in agreement with observations made during bulk sampling and petrographic investigations (Brlek et al. 2014) of primary marine bioclastic packstone as intercalations in calcrete samples. Primary marine packstone remained occluded in secondary calcretes due to its patchy calcretization inside Thalassinoides burrows (Brlek et al. 2014). Such patchy alteration left fragments of primary marine packstone that might have been occluded by secondary rhizogenic calcrete without chemical alteration (Cerling 1999; Michel et al. 2013), and/ or was partially pedo(dia)genetically overprinted (Mindszenty and Deák 1999; see alteration model sensu Wright 1994; Alonso-Zarza and Wright 2010). Alternatively, the recorded anomalies in carbon isotope composition of pedogenic carbonates analyzed here, which probably developed in subaerially exposed platform deposits located close to sea-level position, could have been caused by the influence of high groundwater table, specific hydromorphic conditions, and salinity of pore waters on processes of carbon isotope fractionation (A. Mindszenty, personal communication).

\section{Conclusions}

1. Distinctly negative $\delta^{13} \mathrm{C}$ (and to a lesser extent $\delta^{18} \mathrm{O}$ ) signatures of biogenic calcretes marking the regional $\mathrm{K}-\mathrm{Pg}$ subaerial unconformity in the three analyzed localities from central Dalmatia and eastern Istria differ significantly from carbon isotopic signatures of primary marine limestones, and indicate carbon isotope exchange of primary marine $\mathrm{CaCO}_{3}$ with $\mathrm{CO}_{2}$ released by root and rhizomicrobial respiration and subsequent precipitation of pedogenic calcrete.

2. The $\delta^{13} \mathrm{C}$ (ranging from -13.1 to $-8.2 \%$ VPDB) and $\delta^{18} \mathrm{O}(-10.1$ to $-6.1 \%$ VPDB $)$ values of all calcrete types analyzed here are similar to those reported from calcretes elsewhere, with the $\delta^{13} \mathrm{C}$ values also in the range of calcretes recorded in Recent and Pleistocene subaerially exposed carbonate profiles.

3. The $\delta^{13} \mathrm{C}$ values of all calcrete types, and especially of the second type of biogenic calcretes with typical Microcodium aggregates at the Šibenik locality $\left(\delta^{13} \mathrm{C}\right.$ values ranging from -13.1 to $-12.3 \%$ VPDB), are very close to, or are at the absolute lower limit of, soil carbonates formed in isotopic equilibrium with soil $\mathrm{CO}_{2}$ ( -13 to $-12 \%$ PDB). These values are expected 
for authigenic pedogenic carbonates formed exclusively under the influence of $\mathrm{C}_{3}$ plant communities, and without any apparent input of heavier carbon from pre-existing carbonate deposits or from atmospheric $\mathrm{CO}_{2}$. Although such low $\delta^{13} \mathrm{C}$ values of calcretes support the interpretation of Microcodium aggregates as being precipitated under a direct biological control within the soil, the exact formation mechanisms of Microcodium (e.g., rhizogenic, metabolic activity of rhizosphere microbes) and their influence on stable isotope signatures of authigenic pedogenic carbonates require further investigation.

4. The $\delta^{13} \mathrm{C}$ values ( -4.4 to $-3.6 \%$ VPDB) of rhizogenic calcretes formed inside firmground Thalassinoides burrows of the composite surface at the Šibenik locality are more negative than the $\delta^{13} \mathrm{C}$ values of host marine limestones, and confirm that the composite surface went through a phase of meteoric pedo(dia)genesis. However, the overall $\delta^{13} \mathrm{C}$ values of calcretes are less negative than those expected to have formed under the conditions of prevailing $\mathrm{C}_{3}$ plant communities, and are interpreted to reflect contamination with associated marine carbonates.

Acknowledgments This study was partly supported by the project "Stratigraphy and Geodynamic Context of Cretaceous Deposits in the NE Adriatic Region" (No. 181-1191152-2697) of the Ministry of Science, Education and Sports of the Republic of Croatia. We would like to thank Dr. Martina Gocke and Prof. Andrea Mindszenty for their very helpful comments and suggestions that greatly improved the manuscript. Thanks to Facies Editor-in-Chief Prof. Franz Theodor Fürsich for his helpful comments and editorial work, and to Prof. S. Burns (University of Massachusetts, Amherst, USA) for stableisotope analyses. We would also like to thank Prof. Lj. Babić (University of Zagreb, Croatia) and Dr. T. Korbar (Croatian Geological Survey) for assistance with fieldwork in the Labin-Koromačno area and in central Dalmatia, respectively.

\section{References}

Allan JR, Matthews RK (1982) Isotope signatures associated with early meteoric diagenesis. Sedimentology 29:797-817

Alonso-Zarza AM (1999) Initial stages of laminar calcrete formation by roots: examples from the Neogene of central Spain. Sediment Geol 126:177-191

Alonso-Zarza AM (2003) Palaeoenvironmental significance of palustrine carbonates and calcretes in the geological record. Earth Sci Rev 60:261-298

Alonso-Zarza AM, Arenas A (2004) Cenozoic calcretes from the Teruel Graben, Spain: microstructure, stable isotope geochemistry and environmental significance. Sediment Geol 167:91-108

Alonso-Zarza AM, Jones B (2007) Root calcrete formation on Quaternary karstic surfaces of Grand Cayman. Geol Acta 5:77-88

Alonso-Zarza AM, Wright VP (2010) Calcretes. In: Alonso-Zarza AM, Tanner LH (eds) Carbonates in continental settings: Facies, environments and processes. Developments in sedimentology, vol 61, pp 225-269
Alonso-Zarza AM, Sanz ME, Calvo JP, Estévez P (1998) Calcified root cells in Miocene pedogenic carbonates of the Madrid Basin: evidence for the origin of Microcodium. Sediment Geol 116:81-97

Amundson R, Stern L, Baisden T, Wang Y (1998) The isotope composition of soil and soil-respired $\mathrm{CO}_{2}$. Geoderma 82:83-114

Bajnóczi B, Kovács-Kis V (2006) Origin of pedogenic needle-fiber calcite revealed by micromorphology and stable isotope composition - a case study of a Quaternary paleosol from Hungary. Chem Erde-Geochem 66:203-212

Barta G (2011) Secondary carbonates in loess-paleosoil sequences: a general review. Cent Eur J Geosci 3:129-146

Becze-Deák J, Langohr R, Verrecchia EP (1997) Small scale secondary $\mathrm{CaCO}_{3}$ accumulations in selected sections of the European loess belt. Morphological forms and potential for paleoenvironmental reconstruction. Geoderma 76:221-252

Brlek M, Korbar T, Cvetko Tešović B, Glumac B, Fuček L (2013) Stratigraphic framework, discontinuity surfaces and regional significance of Campanian slope to ramp carbonates from central Dalmatia, Croatia. Facies 59:779-801

Brlek M, Korbar T, Košir A, Glumac B, Grizelj A, Otoničar B (2014) Discontinuity surfaces in Upper Cretaceous to Paleogene carbonates of central Dalmatia (Croatia): Glossifungites ichnofacies, biogenic calcretes and stratigraphic implications. Facies 60:467-487

Burns SJ, Rossinsky V (1989) Late Pleistocene mixing zone dolomitization, southern Barbados, West Indies. Sedimentology 36:1135-1142

Cerling TE (1984) The stable isotopic composition of modern soil carbonates and its relationship to climate. Earth Planet Sci Lett 71:229-240

Cerling TE (1999) Stable carbon isotopes in paleosol carbonates. In: Thiry M, Simon-Coinçon R (eds) Palaeoweathering, palaeosurfaces and related continental deposits. Special publications of the international association of sedimentologists, vol. 27, pp 43-60

Clari PA, Della Pierre F, Martire L (1995) Discontinuities in carbonate successions: identification, interpretation and classification of some Italian examples. Sediment Geol 100:97-121

Ćosović V, Drobne K, Moro A (2004) Paleoenvironmental model for Eocene foraminiferal limestones of the Adriatic carbonate platform (Istrian Peninsula). Facies 50:61-75

Ćosović V, Premec Fuček V, Gušić I, Jelaska V, Moro A (2006) The age of the Tilovica breccias in Central Dalmatia, Croatia. Micropaleontology 52:281-286

Ćosović V, Drobne K, Ogorelec B, Moro A, Koić M, Šoštarko I, Tarlao A, Tunis G (2008) Decastronema barattoloi (De Castro), characteristic fossil of the Palaeocene and the Eocene peritidal sediments from the Adriatic carbonate platform. Geol Croat 61:321-332

Cvetko Tešović B, Gušić I, Jelaska V, Bucković D (2001) Stratigraphy and microfacies of the Upper Cretaceous Pučišća Formation, Island of Brač, Croatia. Cret Res 22:591-613

D’Argenio B, Mindszenty A (1995) Bauxites and related paleokarst: tectonic and climatic event markers at regional unconformities. Eclog Geol Helv 88:453-499

Deák F, Földvári M, Mindszenty A (2002) A new tool to detect exposure surfaces in shallow water carbonate depositional environments. Acta Geol Hung 45:301-317

Deocampo DM (2010) The geochemistry of continental carbonates. In: Alonso-Zarza AM, Tanner LH (eds) Carbonates in continental settings: geochemistry, diagenesis and applications. Development of sedimentary, vol 62 , pp 1-59

Durn G, Ottner F, Tišljar J, Mindszenty A, Barudžija U (2003) Regional subaerial unconformities in shallow-marine carbonate sequences of Istria: sedimentology, mineralogy, geochemistry and micromorphology of associated bauxites, paleosols and 
pedo-sedimentary complexes. In: Vlahović I, Tišljar J (eds) Field trip guidebook, 22nd IAS meeting of sedimentology, Opatija, pp 209-251

Freytet P, Plaziat JC (1982) Continental carbonate sedimentation and pedogenesis-Late Cretaceous and Early Tertiary of southern France. Contrib Sediment 12:213

GKRH (2009) Geološka karta Republike Hrvatske (Geological Map of the Republic of Croatia) scale 1:300.000. Hrvatski geološki institut (Croatian Geological Survey), Zagreb, 1 sheet

Gocke M (2010) Pedogenic carbonates in loess-formation rates, formation conditions and source apportionment assessed by isotopes and molecular proxies. Dissertation, University of Bayreuth

Gocke M, Kuzyakov Y (2011) Effect of temperature and rhizosphere processes on pedogenic carbonate recrystallization: Relevance for paleoenvironmental applications. Geoderma 166:57-65

Gocke M, Pustovoytov K, Kuzyakov Y (2010) Effect of $\mathrm{CO}_{2}$ concentration on the initial recrystallization rate of pedogenic carbonate-revealed by ${ }^{14} \mathrm{C}$ and ${ }^{13} \mathrm{C}$ labelling. Geoderma 155:351-358

Gocke M, Pustovoytov K, Kühn P, Wiesenberg GLB, Löscher M, Kuzyakov Y (2011a) Carbonate rhizoliths in loess and their implications for paleoenvironmental reconstruction revealed by isotopic composition: $\delta^{13} \mathrm{C},{ }^{14} \mathrm{C}$. Chem Geol 283:251-260

Gocke M, Pustovoytov K, Kuzyakov Y (2011b) Carbonate recrystallization in root-free soil and rhizosphere of Triticum aestivum and Lolium perenne estimated by ${ }^{14} \mathrm{C}$ labeling. Biogeochemistry 103:209-222

Gocke M, Pustovoytov K, Kuzyakov Y (2012) Pedogenic carbonate formation: Recrystallization versus migration-process rates and periods assessed by ${ }^{14} \mathrm{C}$ labeling. Glob Biogeochem Cycles 26. doi:10.1029/2010GB003871

Gocke M, Gulyás S, Hambach U, Jovanović M, Kovács G, Marković SB, Wiesenberg GLB (2014) Biopores and root features as new tools for improving paleoecological understanding of terrestrial sediment-paleosol sequences. Palaeogeogr Palaeoclimatol Palaeoecol 394:42-58

Gušić I, Jelaska V (1990) Upper Cretaceous stratigraphy of the Island of Brač within the geodynamic evolution of the Adriatic carbonate platform. Djela Jugosl akad znan umjetn 69:1-160

Hillgärtner H (1998) Discontinuity surfaces on a shallow-marine carbonate platform (Berriasian, Valanginian, France and Switzerland). J Sediment Res 68:1093-1108

Immenhauser A, Creusen A, Esteban M, Vonhof HB (2000) Recognition and interpretation of polygenetic discontinuity surfaces in the Middle Cretaceous Shu'aiba, Nahr Umr and Natih formations of northern Oman. GeoArabia 5:299-322

Jaillard B, Guyon A, Maurin AF (1991) Structure and composition of calcified roots, and their identification in calcareous soils. Geoderma 50:197-210

James NP, Choquette PW (1990) Limestones-the meteoric diagenetic environment. In: McIlreth IA, Morrow DW (eds) Diagenesis. Geoscience Canada reprint series, vol 4, pp 35-75

Jenkyns HC (1991) Impact of Cretaceous sea-level rise and anoxic events on the Mesozoic carbonate platform of Yugoslavia. AAPG Bull 75:1007-1017

Kabanov P, Anadón P, Krumbein WE (2008) Microcodium: an extensive review and a proposed non-rhizogenic biologically induced origin for its formation. Sediment Geol 205:79-99

Klappa CF (1980) Rhizoliths in terrestrial carbonates: classification, recognition, genesis and significance. Sedimentology 27:613-629

Koeniger P, Barta G, Thiel G, Bajnóczi B, Novothny Á, Horváth E, Techmer A, Frechen M (2014) Stable isotope composition of bulk and secondary carbonates from the Quaternary loesspaleosol sequence in Sütto, Hungary. Quat Int 319:38-49
Korbar T (2009) Orogenic evolution of the External Dinarides in the NE Adriatic region; a model constrained by tectonostratigraphy of Upper Cretaceous to Paleogene carbonates. Earth Sci Rev 96:296-312

Košir A (2004) Microcodium revisited: root calcification products of terrestrial plants on carbonate-rich substrates. J Sediment Res $74: 845-857$

Kovačević Galović E, Ilijanić N, Peh Z, Miko S, Hasan O (2012) Geochemical discrimination of Early Palaeogene bauxites in Croatia. Geol Croat 65:53-65

Kraimer RA, Monger HC (2009) Carbon isotopic subsets of soil carbonate-a particle size comparison of limestone and igneous parent materials. Geoderma 150:1-9

Łącka B, Łanczont M, Madeyska T (2009) Oxygen and carbon stable isotope composition of authigenic carbonates in loess sequences from the Carpathian margin and Podolia, as a palaeoclimatic record. Quat Int 198:136-151

Lambers H, Mougel C, Jaillard B, Hinsinger P (2009) Plant-microbesoil interactions in the rhizosphere: an evolutionary perspective. Plant Soil 321:83-115

Li R, Jones B (2014) Calcareous crusts on exposed Pleistocene limestones: a case study from Grand Cayman, British West Indies. Sediment Geol 299:88-105

Lohmann KC (1988) Geochemical patterns of meteoric diagenetic systems and their application to studies of paleokarst. In: James NP, Choquette PW (eds) paleokarst. Springer, Berlin, pp 58-80

Michel LA, Driese SG, Nordt LC, Breecker DO, Labotka DM, Dworkin SI (2013) Stable-isotope geochemistry of vertisols formed on marine limestone and implications for deep-time paleoenvironmental reconstructions. J Sediment Res 83:300-308

Milliere L, Hasinger O, Bindschedler S, Cailleau G, Spangenberg JG, Verrecchia EP (2011) Stable carbon and oxygen isotope signatures of pedogenic needle fibre calcite. Geoderma 161:74-87

Mindszenty A, Deák F (1999) Karbonátos paleotalajok a gerecsei felső triászból (Carbonate paleosols from the Upper Triassic of the Gerecse mountains, Hungary). Fölt Közl (Bull Geol Soc Hung) 129:213-248

Monger HC, Cole DR, Buck BJ, Gallegos GA (2009) Scale and the isotopic record of $\mathrm{C}_{4}$ plants in pedogenic carbonate: from the biome to the rhizosphere. Ecology 90:1498-1511

Moro A, Skelton PW, Ćosović V (2002) Palaeonvironmental setting of rudists in the Upper Cretaceous (Turonian-Maastrichtian) Adriatic Carbonate Platform (Croatia), based on sequence stratigraphy. Cretac Res 23:489-508

Otoničar B (2007) Upper Cretaceous to Paleogene forebulge unconformity associated with foreland basin evolution (Kras, Matarsko podolje and Istria; SW Slovenia and NW Croatia). Acta Carsol 36:101-120

Otoničar B, Košir A, Ćosović V (2003) Cretaceous-Tertiary paleokarst from Koromačno (Istria, NW Croatia): an example of paleokarstic denuded cave. In: Vlahović I (ed) 22nd IAS meeting of sedimentology: abstracts book, Opatija, p 2003

Pamić J, Gušić I, Jelaska V (1998) Geodynamic evolution of Central Dinarides. Tectonophysics 297:273-307

Pustovoytov K, Terhorst B (2004) An isotopic study of a late Quaternary loess-paleosol sequence in SW Germany. Revista Mexicana de Ciencias Geológicas 21:88-93

Pustovoytov K, Schmidt K, Taubald H (2007) Evidence for Holocene environmental changes in the northern Fertile Crescent provided by pedogenic carbonate coatings. Quat Res 67:315-327

Rossinsky V, Wanless HR, Swart PK (1993) Penetrative calcretes and their stratigraphic significance. Geology 20:331-334

Sakač K, Šinkovec B (1991) The bauxites of the Dinarides. Travaux ICSOBA 20-21:1-11

Salomons W, Mook WG (1986) Isotope geochemistry of carbonates in the weathering zone. In: Fritz P, Fontes JCh (eds) Handbook 
of environmental isotope geochemistry, vol 2. Elsevier, Amsterdam, pp 239-269

Schweitzer CE, Shirk AM, Ćosović V, Okan Y, Feldmann RM, Hoşgör I (2007) New species of Harpactocarcinus from the Tethyan Eocene and their paleoecological setting. J Paleontol 81:1091-1100

Šnkovec B (1973) The origin of early Paleogene bauxites of Istria, Yugoslavia. 3eme Congr Intern d'ICSOBA Nice 1973, pp 151-164

Steuber T, Korbar T, Jelaska V, Gušić I (2005) Strontium-isotope stratigraphy of Upper Cretaceous platform carbonates of the Island of Brač (Adriatic Sea, Croatia): implications for global correlation of platform evolution and biostratigraphy. Cret Res 26:741-756

Talma AS, Netterberg F (1983) Stable isotope abundances in calcretes. In: Wilson RCL (ed) Residual deposits: surface related weathering processes and materials. Special Publications Geological Society London, vol 11, pp 221-233

Tanner LH (2010) Continental carbonates as indicators of paleoclimate. In: Alonso-Zarza AM, Tanner LH (eds) Carbonates in continental settings: geochemistry, diagenesis and applications. Developments in sedimentology, vol 62, pp 179-214

Velić I (2007) Stratigraphy and palaeobiogeography of Mesozoic benthic foraminifera of the Karst Dinarides (SE Europe). Geol Croat 60:1-113

Vlahović I, Tišljar J, Velić I, Matičec D (2005) Evolution of the Adriatic Carbonate Platform: palaeogeography, main events and depositional dynamics. Palaeogeogr Palaeoclimatol Palaeoecol 220:333-360
Wang H, Greenberg SE (2007) Reconstructing the response of $\mathrm{C}_{3}$ and $\mathrm{C}_{4}$ plants to decadal-scale climate change during the late Pleistocene in southern Illinois using isotopic analyses of calcified rootlets. Quat Res 67:136-142

Wright VP (1994) Paleosols in shallow marine carbonate sequences. Earth Sci Rev 35:367-395

Wright VP, Tucker ME (1991) Calcretes: an introduction. In: Wright VP, Tucker ME (eds) Calcretes. IAS reprint series, vol 2, pp 1-22

Wright VP, Platt NH, Marriot SB, Beck VH (1995) A classification of rhizogenic (root-formed) calcretes, with examples from the Upper Jurassic-Lower Carboniferous of Spain and Upper Cretaceous of southern France. Sediment Geol 100:143-158

Zamagni J, Mutti M, Košir A (2008) Evolution of shallow benthic communities during the late Paleocene-earliest Eocene transition in the northern Tethys (SW Slovenia). Facies 54:25-43

Zhou J, Chafetz HS (2009a) The genesis of late Quaternary caliche nodules in Mission Bay, Texas: stable isotopic compositions and palaeoenvironmental implications. Sedimentology 56:13921410

Zhou J, Chafetz HS (2009b) Biogenic caliches in Texas: the role of organisms and effect of climate. Sediment Geol 222:207-225

Zhou J, Chafetz HS (2010) Pedogenic carbonates in Texas: stable isotope distributions and their implications for reconstructing region-wide paleoenvironments. J Sediment Res 80:137-150 